\title{
GEOLOGY OF THE ENGIGSTCIAK ARCHAEOLOGICAL SITE, YUKON TERRITORY
}

\author{
J. R. Mackay,* W. H. Mathews,** and R. S. MacNeish****
}

$\mathbf{F}$ on some years students of human history have hoped and expected to find a record of human occupation in the Arctic of western Canada and Alaska comparable in antiquity to the now rather numerous "Early Man" sites of the central and southwestern United States. The Engigstciak site (discovered by MacNeish in 1954) near the mouth of the Firth River, Yukon Territory, Canada (Fig. 1), appears to contain such a record in the form of typologically old-looking flint artifacts intimately associated with the bones of extinct animals. The rich artifact assemblage also includes objects assignable on typological grounds to much later cultures, some of which are already well known in other parts of the Arctic. It is clear that the site has been occupied repeatedly throughout much of post-glacial time.

Unfortunately, the natural processes of soil movements of an arctic climate, acting upon especially frost-susceptible sediments, has almost completely destroyed the original stratigraphic relationships in some parts of the archaeological site. In a few places there has been an intimate mixing of soil particles, plant remains, and artifacts of diverse ages, and in other places the differential movement of older materials down-slope over younger materials has resulted in the reversal of the original stratigraphic sequence. Artifacts and bones of extinct and living animals have clearly been involved in the soil movements, so a close physical juxtaposition between a given artifact and a given bone fragment, or micro-fossil-bearing soil specimen, does not necessarily indicate a close age relationship. The problems are further complicated by the probability that a widespread marine silty clay covering the site arrived at its present position by glacial transportation from considerably lower altitudes.

Engigstciak (new or youthful mountain in Eskimo), from which the site derives its name, is a low but rugged eminence in the foothills of the British Mountains, the eastern extension into the Yukon Territory of the

*Department of Geography, University of British Columbia.

**Department of Geology, University of British Columbia.

***Senior Archaeologist, Human History Branch, National Museum of Canada. 
Brooks Range of Alaska (Fig. 1). Its summit (Fig. 2), about 575 feet above sea-level, provides an unobstructed view northeasterly across the tundracovered coastal plain to Herschel Island and the Arctic Ocean, southeasterly and northwesterly (Fig. 8) across several miles of barren lowlands to its nearest neighbouring foothills, and southwesterly up the treeless valley floor of Firth River toward the 5000-foot peaks of the British Mountains. A few hundred feet west of this lookout is a small rounded plateau summit (altitude 480 feet), which drops sharply northward and westward to the level of Firth River, and southward somewhat less abruptly to the highest

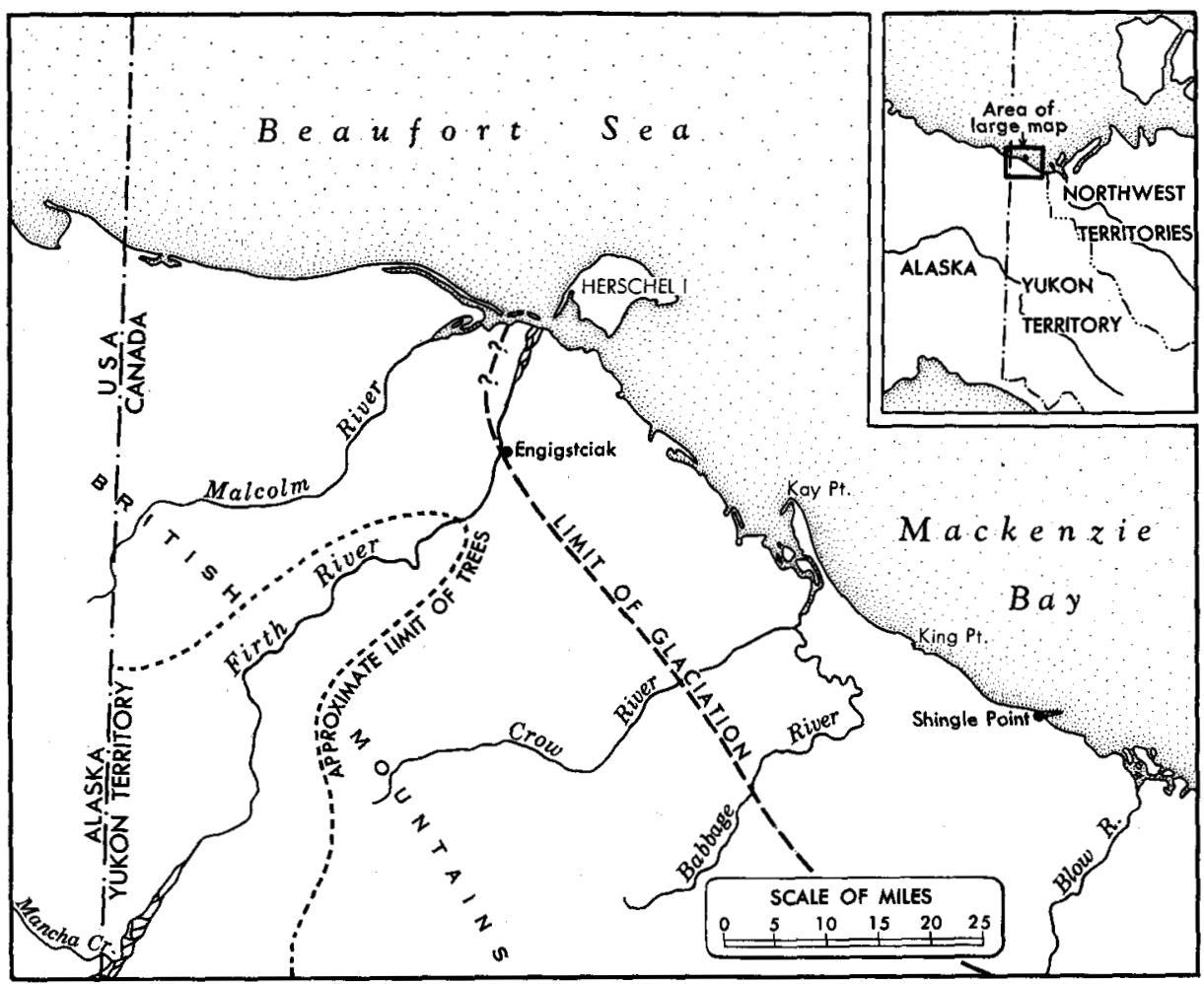

Fig. 1. Location map. Limit of glaciation mainly after Bostock (1948).

of the terraces of the Firth River. Roughly 1 mile southwest of the lookout Firth River leaves a steep-walled canyon cut for miles into the rocky floor of the valley and enters a wide flood plain marked by a network of braided channels and gravel bars. To the prehistoric inhabitants of this region Engigstciak, it seems, presented a particular appeal; the summit offered an unsurpassed view of the tundra to the hunter in his search for the larger game animals on which he depended for food; the canyon of Firth River diverted these animals in their east-west migrations to within hunting range of the locality; the plateau nearby provided campsites better drained than 
the ground to the south, east, or north; Firth River at times yielded fish for food; and driftwood, carried from the forested banks of upper Firth River, was available for fuel. Investigations show that though climatic and ecological conditions have varied, this site has proved favourable for occupation by nomadic hunters throughout a long span of time.

The archaeological significance of this site was first recognized by MacNeish, who in company with a local Eskimo, Old Roland, discovered artifacts here in August 1954. Excavations were carried out in the summers of 1955,1956 , and part of 1958 on the crest and south slopes of the plateau west of Engigstciak. It became evident in 1955 that a large and varied cultural record was available at this site and that with some artifacts occurring under grey marine clay (MacNeish 1956) now at an altitude of 460 feet above sea-level, these might be linked to an extended geological history. To relate further the geological history to the archaeological finds, Mackay and Mathews spent 17 days at Engigstciak in August and September 1956, working with MacNeish (Mackay and Mathews 1956). In August 1957 Mackay revisited the site and spent a week there conducting field investigations.

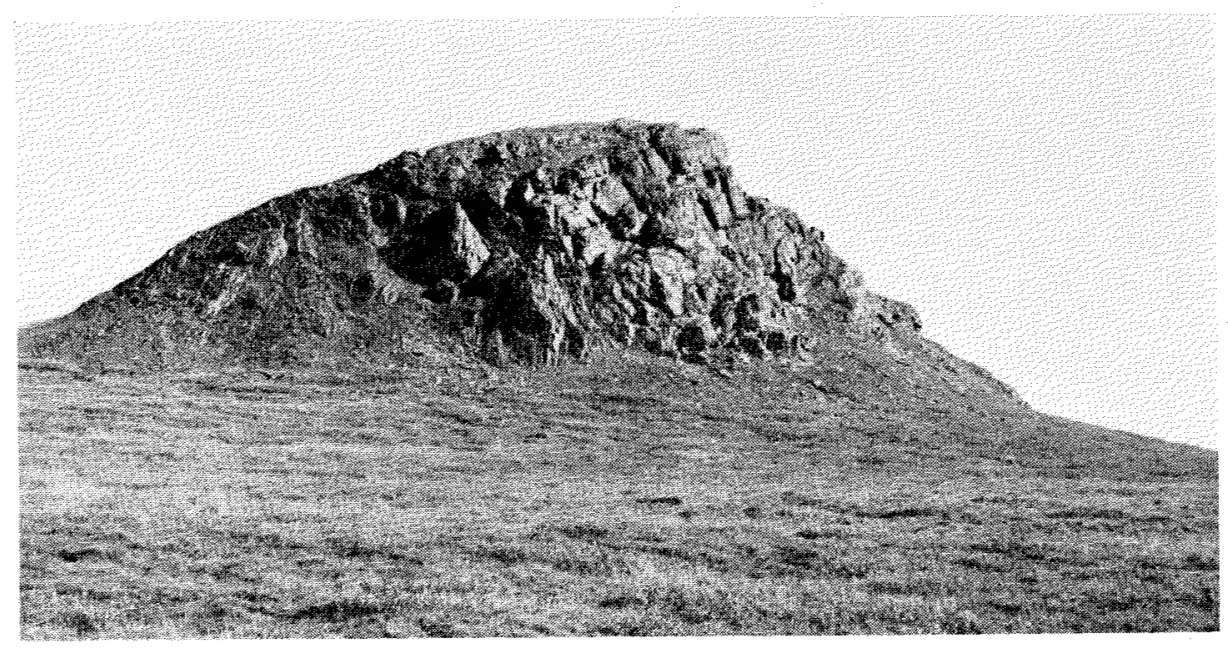

Fig. 2. Looking north at the south face of Engigstciak. The rock cliff, centre foreground, is about 100 feet high.

\section{Quaternary sediments}

The area in the immediate vicinity of the archaeological finds (Fig. 3) is almost completely devoid of natural exposures of the Quaternary succession. The main sources of information on the sequence of layers consist of the archaeological excavations, whose sides expose more than 1000 linear feet of sections, and some 190 pits dug specifically for geological data. The 
pits are spaced at intervals of 100 to 200 feet in areas relatively uniform in succession; in areas with a more complex succession or where one type of succession merges into another, pits are spaced as closely as several feet apart. The archaeological excavations and the pits are limited in depth by the permafrost table which lies from about 18 to 43 inches below the surface. However, as some excavations have been continued over four consecutive summers, thawing has permitted a few of the older pits to be deepened as much as 4 feet below the original permafrost table.

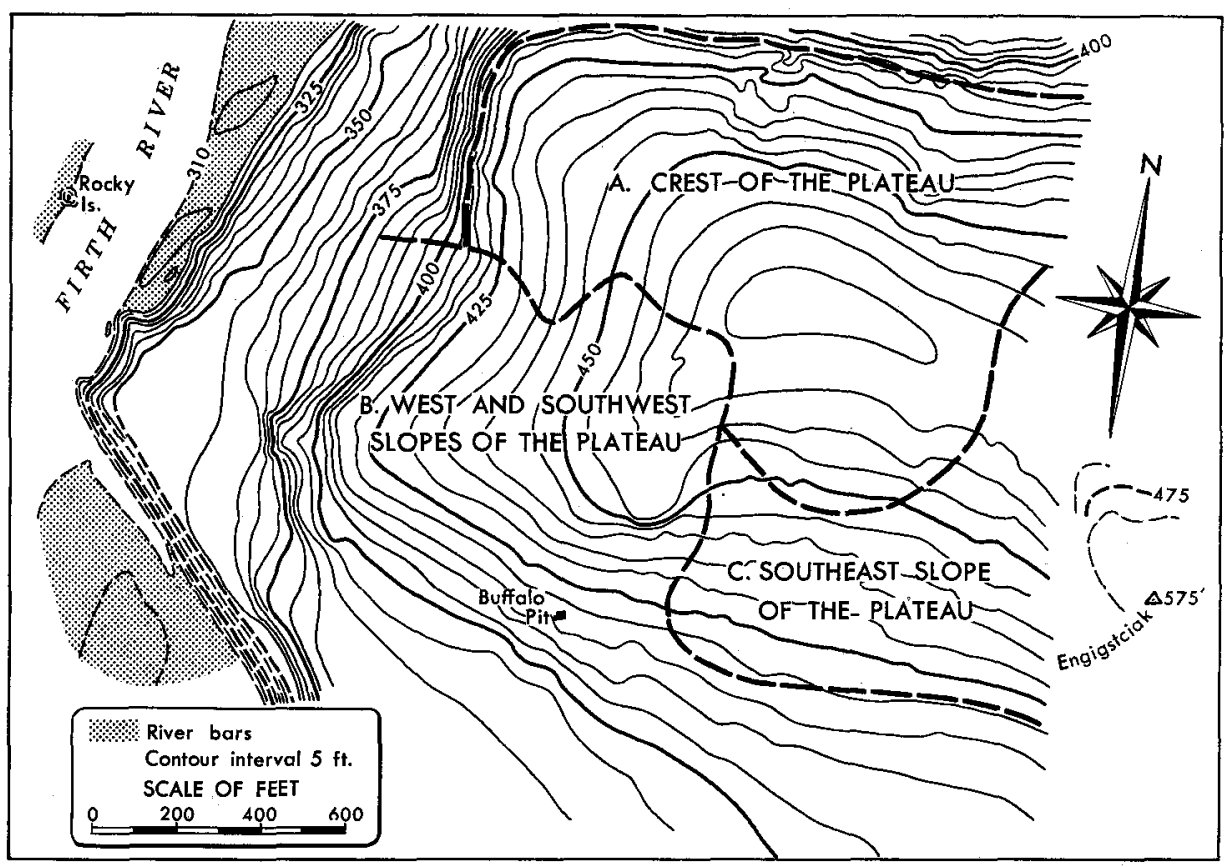

Fig. 3. Engigstciak archaeological site. The altitudes of Engigstciak ( $575 \mathrm{feet}$ ) and Firth River ( 310 feet) are taken from a map prepared by the Topographical Survey, Ottawa. The 5-foot contours have been mapped by both plane-table with telescopic alidade and Abney level and stadia-rod methods.

The Quaternary beds have been disturbed by the growth and melting of ground ice, intense frost heaving, solifluction, and the formation of patterned ground. As a result the sequence of layers does not everywhere represent the superposition of younger beds upon older ones; in many and perhaps most - places overturning, repetition, and physical mixing of beds of different ages has clearly taken place. To avoid the suggestion that the sequence of beds found at the site has necessarily a stratigraphic significance, the layers are described in succession from the surface downward, rather than in the customary geological succession. Moreover, since the succession differs markedly in three more or less distinct but adjacent areas each area is considered separately (Fig. 3). 


\section{A. Crest of the plateau}

Limits: A well-defined break in slope (altitude 415 feet) following a strip of shoreline gravels believed to be lacustrine, marks the northern and western limits of the area in question. The southern limit is poorly defined topographically (Fig. 3), but lies close to a line of bedrock outcrops (Fig. 4) extending northwesterly from Engigstciak. The eastern limit has not been mapped.

Surface vegetation. The tundra vegetation of this area consists of abundant grasses and sedges, 12 to 15 inches high, low shrubby willows, generally spaced at intervals of less than 3 feet, dominating in height though not in areal extent over other plants, with smaller amounts of avens (Dryas), prostrate willows (Salix reticulata), lupins, etc. and mosses in depressions. Hummocks 2 to 3 feet across and 2 to 18 inches high, with bounding vegetation-filled depressions, are general. A few poorly developed tundra (ice-wedge) polygons, 25 to 75 feet in diameter, are present.

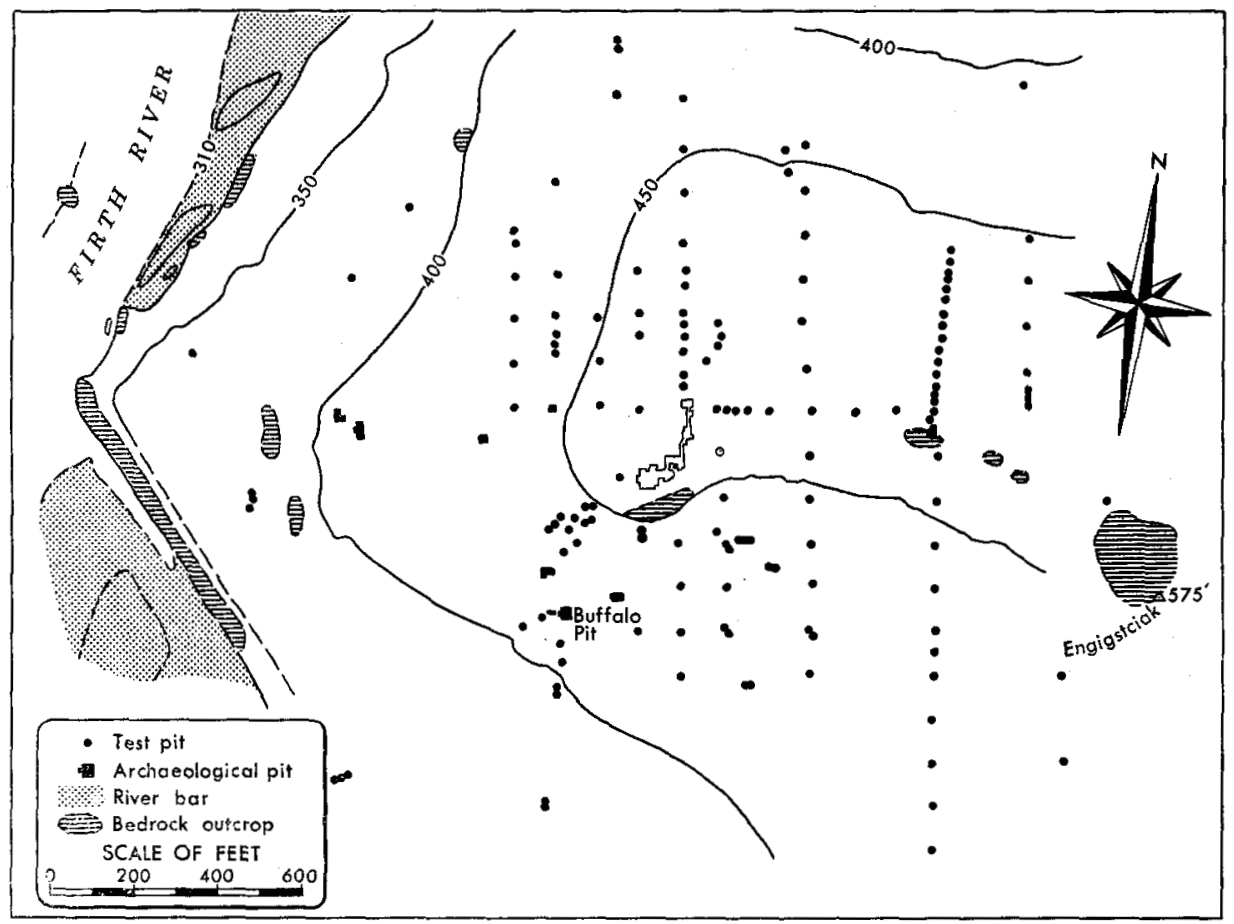

Fig. 4. Map showing test pits, archaeological pits (excavations), and bedrock outcrops.

Turf. The turf consists of a brownish grey (colour terminology follows that in the Munsell colour chart) sand to silty sand loosely bonded by living, dead, and partly decomposed plant roots. It either grades into, or is sharply separated from the underlying clay, depending on whether it is on 
the top or side of the hummocks. The thickness of the horizon shows a relationship to the ill-defined pattern of hummock cracks on the ground surface, extending to greatest depth - in excess of 7 inches - below the cracks and being thin or absent in the hummock centres where locally the clay is present at the surface in frost boils.

Olive-grey marine clay. An olive-grey, slightly calcareous and somewhat stony marine "clay" from 13 to 34 inches thick underlies the much sandier turf (Table 1, specimens 1, 4,5). Mechanical analyses show it to contain nearly equal amounts of clay-size, silt-size, and sand-plus-pebble fractions. The stones present in this sediment include red granitic and gneissic pebbles, and boulders typical of glacial detritus from the Canadian Shield, although possibly nine-tenths of the stones are of local origin. The clay has a distinctly granular structure. Its colour tends to become somewhat yellowish-green with depth. Three samples from different levels and different localities have been examined for microfossils. All have yielded some remains (Table 2, specimens 2, 3, 4). The species are known from late Pleistocene formations and from the waters off the Yukon coast at depths of from 18 to 20 fathoms. No freshwater forms were found. Additional information helpful in the separation of marine and freshwater glacial clays, is given in Appendix 1 on soil-mechanics tests.

Buried organic layer. A dark organic layer varying from humus-rich silt or clay to well-decomposed clayey or silty muck generally underlies the olive-grey marine clay, and usually is underlain in turn by a yellow-green clay. Locally, grey sand has been found in association with the organic layer, but elsewhere this sand is lacking. The organic layer, though of very great horizontal extent on the upper part of the plateau, is interrupted in many places by plugs of yellow-green clay, apparently intruded from below as a result of frost action.

As a rule the organic material rests directly on the yellow-green clay, but locally it overlies sand or frost-shattered bedrock. The basal contact is commonly so clearly defined that the layers may be separated with a knife. No traces of a root system or buried soil profile are observed in the underlying sediment. In general, the organic layer is located close to the permafrost table, lying rarely more than a few inches above permafrost and commonly immediately above it or even extending into it.

The upper limit of the organic layer is streaky, disturbed by frost action, and generally ill-defined. Organic material occurring in the turf may extend downward in the vicinity of hummock boundaries as a continuous curtain to join the organic layer (Fig. 5). Because of the uncertain upper limit of this layer its thickness is hard to establish, but a somewhat arbitrary average figure is 3.5 inches and the maximum recorded is 7 inches.

The organic layer has yielded pollen, numerous animal bones, and bone fragments, particles of wood, charcoal, sphagnum moss (some in a remarkably fresh state), and crude artifacts of the British Mountains complex (MacNeish 1956). The pollen from this layer includes white and 
black spruce (19 grains), alder (19), birch (including some Betula papyrifera) (17), willow (9), and pine (jack or lodgepole) (4), together with smaller amounts of non-arboreal forms (23). This assemblage indicates a warmer climate than the present, judging from comparisons with pollen from higher horizons at this site, as well as from pollen spectra of lake deposits of northern Alaska (Livingstone 1955, 1957). The wood fragments appear to be made up in large part of spruce and willow roots, or branches or both. A C-14 (University of Michigan) date on one of the wood fragments (willow) was 1,560 years B.P.

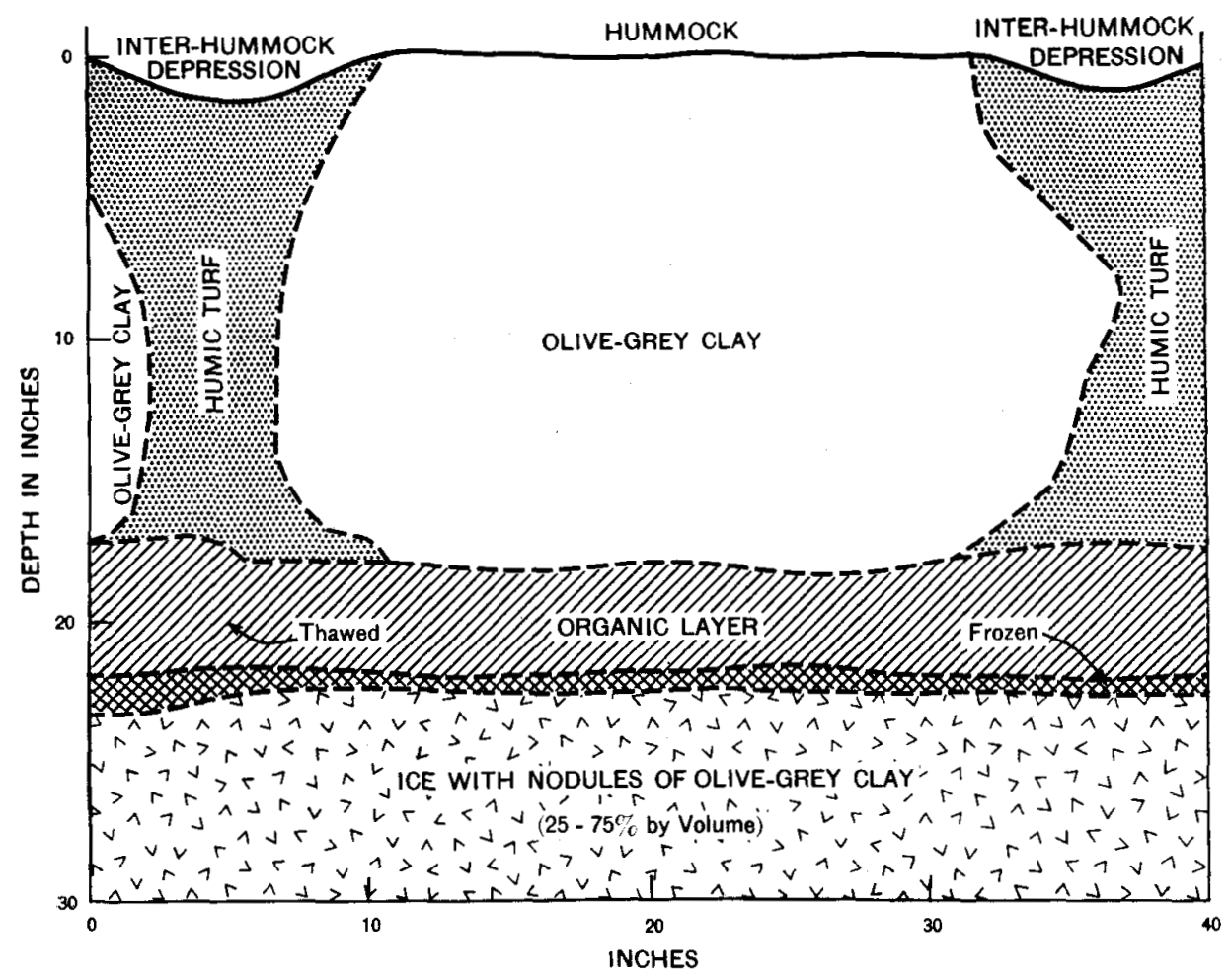

Fig. 5. Section through a hummock on the crest of the plateau showing the humic turf (under inter-hummock depressions) extending as a continuous curtain from the surface to the organic layer. Note the ground ice below the organic layer.

Yellow-green marine clay. The deepest of the Quaternary sediments exposed in this area consists of a slightly calcareous, stiff, dusky yellowgreen, somewhat stony clay. A maximum of $\mathbf{1 0}$ inches of this material has been observed between the overlying organic layer and the permafrost table. Several excavations were made in the yellow-green clay to a depth of a foot below the permafrost table, but nowhere has the base been seen. The sediment, which consists of about equal parts of clay, silt, and sand-plusgravel fractions (Table 1 , specimens $6,7,8$ ) is characterized by locally 
derived rocks and by scattered pebbles of reddish granitic and gneissic rocks typical of glacial detritus originating in the Canadian Shield. No structure is evident in the clay other than numerous small ice segregations in the form of lenses, pellets, veins, and stringers in the frozen ground. The clay remains plastic enough to be kneaded by hand even though its temperature is below $0^{\circ} \mathrm{C}$. and ice segregations are present. Microscopic examination (Table 2, specimens $6,7,8$ ) shows marine foraminifera in one sample of the yellow-green clay and no fossils in the others. These foraminifera are known from late Pleistocene deposits in this region and are still living off the Yukon coast in depths of from 10 to 112 fathoms. No freshwater forms have been found.

Table 1. Analyses of soil samples.

\begin{tabular}{|c|c|c|c|c|c|c|c|c|}
\hline \multirow[b]{2}{*}{ Location } & \multirow{2}{*}{$\begin{array}{c}\text { Specimen } \\
\text { number }\end{array}$} & \multicolumn{3}{|c|}{ Plasticity } & \multicolumn{3}{|c|}{ Grain size in per cent } & \multirow{2}{*}{$\begin{array}{c}\text { Activity } \\
\text { value }\end{array}$} \\
\hline & & $\begin{array}{l}\text { Liquid } \\
\text { limit }\end{array}$ & $\begin{array}{l}\text { Plastic } \\
\text { limit }\end{array}$ & $\begin{array}{l}\text { Plasticity } \\
\text { index }\end{array}$ & $\begin{array}{c}\text { Clay } \\
\text { less than } \\
0.002 \mathrm{~mm} .\end{array}$ & $\begin{array}{l}\text { Sill } \\
0.002-0.060 \\
m m .\end{array}$ & $\begin{array}{c}\text { Sand } \\
\text { more than } \\
0.060 \mathrm{~mm} .\end{array}$ & \\
\hline \multirow{6}{*}{$\begin{array}{c}\text { Crest } \\
\text { of } \\
\text { plateau }\end{array}$} & 1 & 34.7 & 20.7 & 14.0 & 38 & 42 & 20 & 0.37 \\
\hline & 4 & 26.7 & 21.4 & 5.3 & 20 & 30 & 50 & 0.26 \\
\hline & 5 & - & - & 一 & 20 & 33 & 47 & - \\
\hline & 6 & 49.5 & 41.1 & 8.4 & 26 & 56 & 18 & 0.32 \\
\hline & 7 & 37.5 & 28.3 & 9.2 & 30 & 33 & 34 & 0.31 \\
\hline & 8 & 32.1 & 17.6 & 14.5 & 36 & 40 & 24 & 0.40 \\
\hline \multirow{4}{*}{$\begin{array}{l}\text { South- } \\
\text { west } \\
\text { slope }\end{array}$} & 9 & - & - & - & 19 & 25 & 56 & - \\
\hline & 10 & 22.3 & 15.4 & 6.9 & 18 & 32 & 50 & 0.38 \\
\hline & 11 & 36.7 & 18.3 & 18.4 & 32 & 34 & 34 & 0.57 \\
\hline & 12 & - & - & 一 & 4 & 13 & $\begin{array}{l}20 \% \text { gravel } \\
63 \% \text { sand }\end{array}$ & - \\
\hline \multirow{3}{*}{$\begin{array}{l}\text { Miscel- } \\
\text { laneous }\end{array}$} & 14 & 32.7 & 22.3 & 10.4 & 23 & 25 & 42 & 0.45 \\
\hline & 15 & 35.4 & 26.3 & 9.1 & 20 & 25 & 42 & 0.45 \\
\hline & 16 & 45.7 & 32.5 & 13.2 & 32 & 44 & 24 & 0.41 \\
\hline
\end{tabular}

The yellow-green clay has been distinguished from the younger olivegrey clay not only on the basis of its position under the organic layer but also, when freshly excavated, on the basis of colour, lack of granular structure, a greater stiffness in samples with natural water content and generally a greater number of stones. Mechanical analyses show it to have usually a higher proportion of clay than the shallower deposit. The differences between the two clays were however much less apparent when sections excavated in 1956 had been exposed to a year's weathering and were re-examined in 1957. Mechanical analyses (Table 1, specimens 1, 4, 
$5,6,7,8)$ indicate an overlapping of many properties of the two clays. It is highly probable that colour, structure, and stiffness are secondary features developed by pedological processes and determined in large part by depth below the ground surface or above the permafrost table. Thus an isolated mass of clay moved by frost action, solifluction, or other means from its original position cannot with full assurance be correlated with either clay.

Table 2. Distribution of fossils.

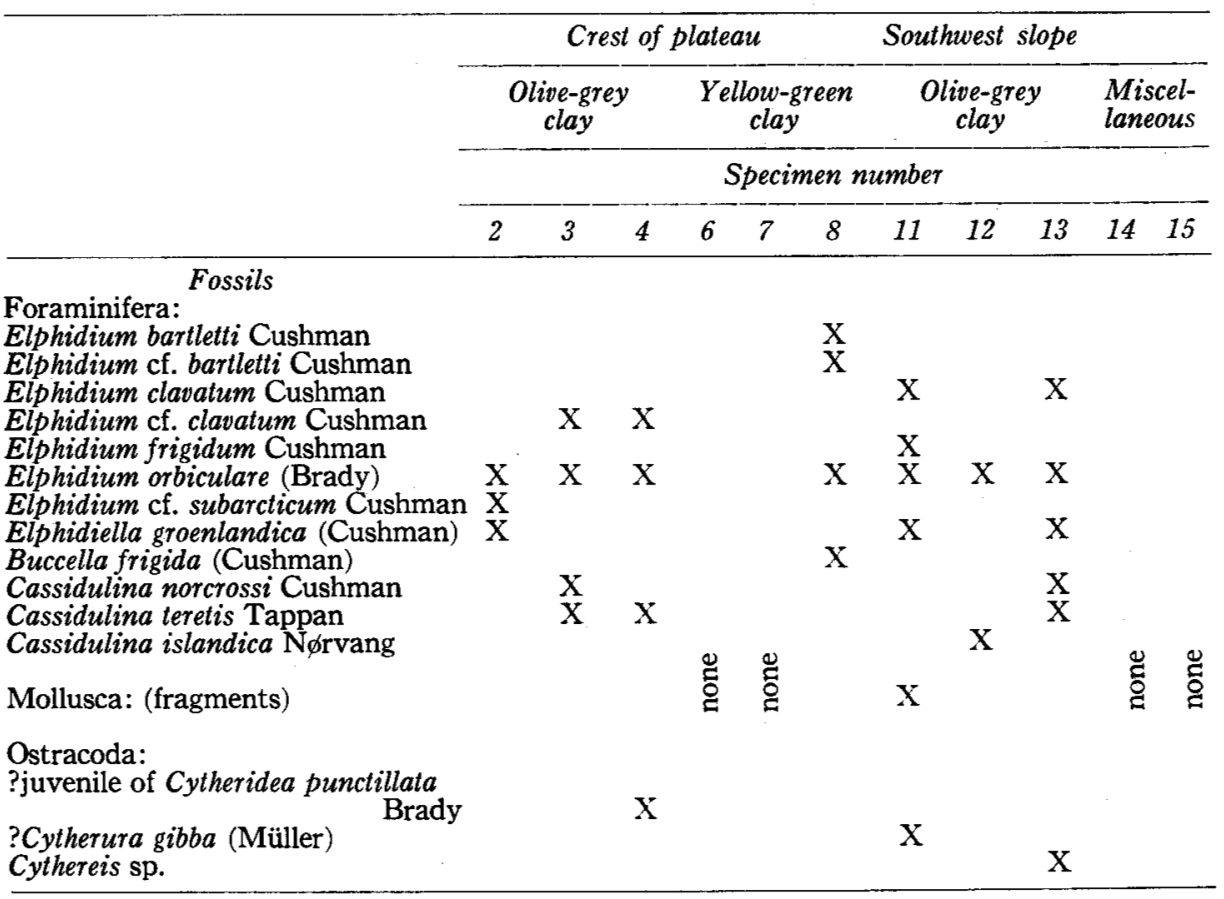

\section{B. West and southwest slopes of the plateau}

Limits. This region abuts on the northeast against the area already discussed and extends south down-slope to the level of a terrace (altitude 395 feet), which is mantled with sandy alluvium devoid of archaeological remains. The eastern limit is marked by a change in microtopography and in vegetation (Fig. 3).

Surface vegetation. Avens (Dryas) dominates in this area, reflecting the rather well-drained sandy soil. Shrubby willows are present but notably less abundant than in the area previously described. Prostrate willows (Salix reticulata), bearberry, and mosses are common in depressions and lichens occur locally. Hummocks 12 to 18 inches across and a few inches high are present in the southern part of this area but are less well developed on the lower slopes.

Turf and humic sands. In most of the area the brownish sand, evidently coloured by incorporation of decomposed organic matter or humus, has a 
thickness of 4 to 36 inches. The upper turfy part is rather darker than the rest and richer in plant roots. However, the vertical changes in colour and abundance of rootlets are very gradual and no satisfactory boundary between the turf and the underlying 'humic sands' has been established. Usually the lower limit of the humic sands is clearly marked by a sharp, though undulating to irregular contact, either with an olive-grey sand devoid of humic streaks or with an olive-grey clay. In the humic sands a streaky colour banding, from horizontal to highly contorted, is evident in some places. Layers or lenses of olive-grey sand are common at depth in some localities. Elsewhere the colour is fairly uniform. Nearly all the humic sands and the turfy horizons are fine-grained and free from stones. However, for approximately 100 feet down-slope from one of the bedrock outcrops, chips of weathered shale are found throughout the upper parts of the sand. Bone fragments, charcoal, and artifacts are common. Among the bones are those of caribou, musk ox, sheep, fox, grizzly bear, moose, rodents, fish, birds, and sea mammals in the upper part; caribou, modern bison, wapiti, mountain sheep, goat, small mammals, fish, birds, and seal are represented in the lower part.

A caribou antler from this horizon has been dated (University of Pennsylvania, P. 228), as 3250 B.P. However it is felt (Rainey and Ralph 1959) that "antler dates are erroneously young and that the discrepancy increases with age." Given a 25 per cent error, indicated by other work, this material may be as much as 4000 years old.

The humic stain may have been formed partly by the progressive burial of the organic material in cracks between hummocks, by a turfy soil horizon related to the present surface, and by aeolian deposition of sand on a turf similar to the one now covering the surface. Significantly, the thickness of the humic zone is greater under the vegetation hummocks than under the cracks bounding the hummocks (Fig. 6).

Olive-grey sand. Olive-grey sand is present not only as streaks and discontinuous lenses within the humic sands, but also as a relatively thick and pure layer underlying the humic sands. As much as 14 inches of clean grey sand has been observed in several of the pits, particularly on the lower part of the south slope. In most places the lower limit of the sand was not reached because of permafrost. In a few pits the sand is underlain by clay and in one by gravel and clay.

Clay lenses. In many places on the higher slopes lenses of olive-grey clay occur either wholly within the olive-grey sand or at its upper contact. Rarely do these lenses exceed 2 inches in thickness, and commonly they are only a few feet long. They are found in many places in anticlinal folds, with axial planes coinciding with cracks between hummocks (Fig. 6). It is evident that the clay together with associated olive-grey sands and the overlying humic sands have been affected by frost movements.

The correlation of the olive-grey clay in this succession with one of the two clays in the succession on the crest and north slopes of the plateau 
is at once suggested. However, colour and structure, as has been noted, are regarded as unreliable criteria. The marine fauna of the grey clay (Table 2, specimens 12 and 13) suggests a correlation with the upper (olive-grey) clay if the two are stratigraphically distinct.

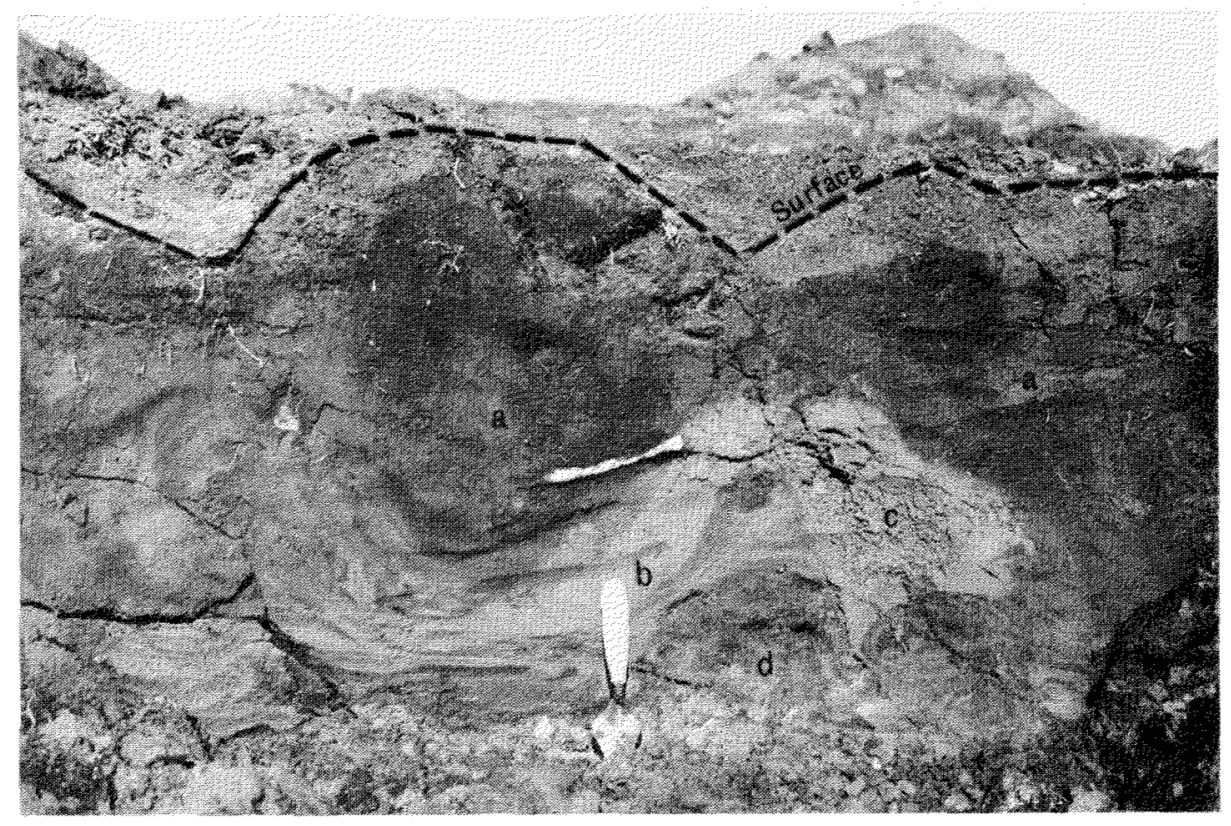

Fig. 6. Contorted beds, showing anticlines and synclines, on the southwest side of the plateau: a) brownish sand below a silty turf; b) olive-grey sand; c) injected plug of olive-grey clay; d) dark brown and grey streaked silty sand. Below the trowel is a 1-to 5-inch organic layer resting on stonefree olive-grey sand, then ground ice at a depth of about 32 inches (August 19) below the surface.

Organic layer. A discontinuous organic layer, occurring under humic and olive-grey sands on the upper southwest slope of the plateau, is of considerable importance from an archaeological standpoint. It lies close to or immediately above the permafrost table, but is locally seen to be underlain by more olive-grey sand, or by yellow-green clay, and in two places by bedrock. The layer, though made up principally of decomposed organic matter, now a blackish muck, also contains some plant fragments so fresh, for example, that some willow leaves are still greenish and sphagnum moss is yellowish green. Pollen obtained from this layer is richer in tree species - spruce (34 grains), alder (20), birch (14), willow (9), pine (3), and nonarboreal (51) - than that from any of the higher horizons. The layer also contains primitive artifacts of the British Mountains complex (MacNeish 1956). Vertebrate remains include bones of a large bison, caribou, and a jaw, probably of a horse. 
A correlation with the organic layer of the crest and north slope is suggested by similarities in depth and in its organic and archaeological contents.

Structural disturbances. As already indicated, contacts and colour bands in the succession are notably disturbed. On gentle slopes folds (Fig. 6) are conspicuous, with synclines containing abnormally great thicknesses of humic sand lying under the hummock centres. On slopes of from $5^{\circ}$ to $7^{\circ}$ the same folds are evident, but are overturned down slope (Fig. 7). On slopes of $7^{\circ}$ to $9^{\circ}$ some sliding has occurred on the overturned limbs of anticlines, and thrust faults are locally in evidence. In one vertical section what is believed to be a single bed of olive-grey clay has been broken and repeated by thrusting four times. Such disturbances appear to be largely confined to the uppermost 20 inches of the soil, because the organic layer close to the permafrost table lacks significant folding or faulting. It is clear from the superficial character of the folds in relationship to hummocks and to angle of slope, that they are a product of secondary soil movements and are not original structures. The total distance any particle has moved since original deposition is undeterminable, but the crumpling is sufficiently extensive so that displacements of many feet, or scores of feet, seem probable. The discontinuities and duplications in such horizons as the olive-grey clay are evidently a reflection of non-uniform displacements and thrust faulting, as are the solifluction lobes, so apparent on the lower slopes. It is surprising indeed that any general succession of beds is recognizable.

Local succession at the "Buffalo Pit". A variant of the succession described above is found on the lower southern slope of the plateau where one of the more important archaeological finds was made. Here, in the "Buffalo Pit", (altitude 410 to 420 feet), dug into the toe of a solifluction lobe, the turf is about 6 inches thick. Below this is a layer of humic sand, 3.5 to 27 inches thick, slightly contorted, showing with increasing depth a distinct banding resulting from the alternation of dark humus-rich and pale organic-poor sands. The lower part of these humic sands contains Arctic Small Tool artifacts (New Mountain culture, MacNeish 1956) as well as bones, including caribou, sheep, rodents, and the remains of one wapiti. This zone grades downward into a streaky pale brown sand from 9 to 19 inches thick, showing pronounced contortions. This in turn rests with a sharp contact on a homogeneous yellowish sand from 12 inches to at least 36 inches thick. The streaky brown sand and the yellowish sand, near their contact, contain artifacts (Flint Creek culture, MacNeish 1956) associated mainly with a large buffalo (either Bison bison athabasci, with premolars like those of extinct forms, or a related subspecies), a few caribou and bird bones, and with pollen indicative of a cool or cold period. In two profiles the yellowish sand was found to overlie at least 30 inches of olive-grey sand comparable to the sand exposed on the higher slopes.

In a pit immediately adjacent to the solifluction lobe on the west both the streaky pale brown sand and the homogeneous yellowish sand are 
absent, and the upper limit of the olive-grey sand lies at an altitude concordant with that in the Buffalo Pit. The solifluction lobe thus appears to have developed by accumulation of what are now the pale brown and yellowish sands on a regular surface underlain by the olive-grey sand. The thickness of combined turf and humic sands is comparable both on and off the lobe, and assuming these two layers to be the combined product of weathering and of accumulation of wind-blown sand and vegetation, the solifluction lobe must have formed at an early stage of soil development and has been relatively stable since then. This early date of origin is also indicated by the lack of any weathering profile below the yellowish sands of the lobe.

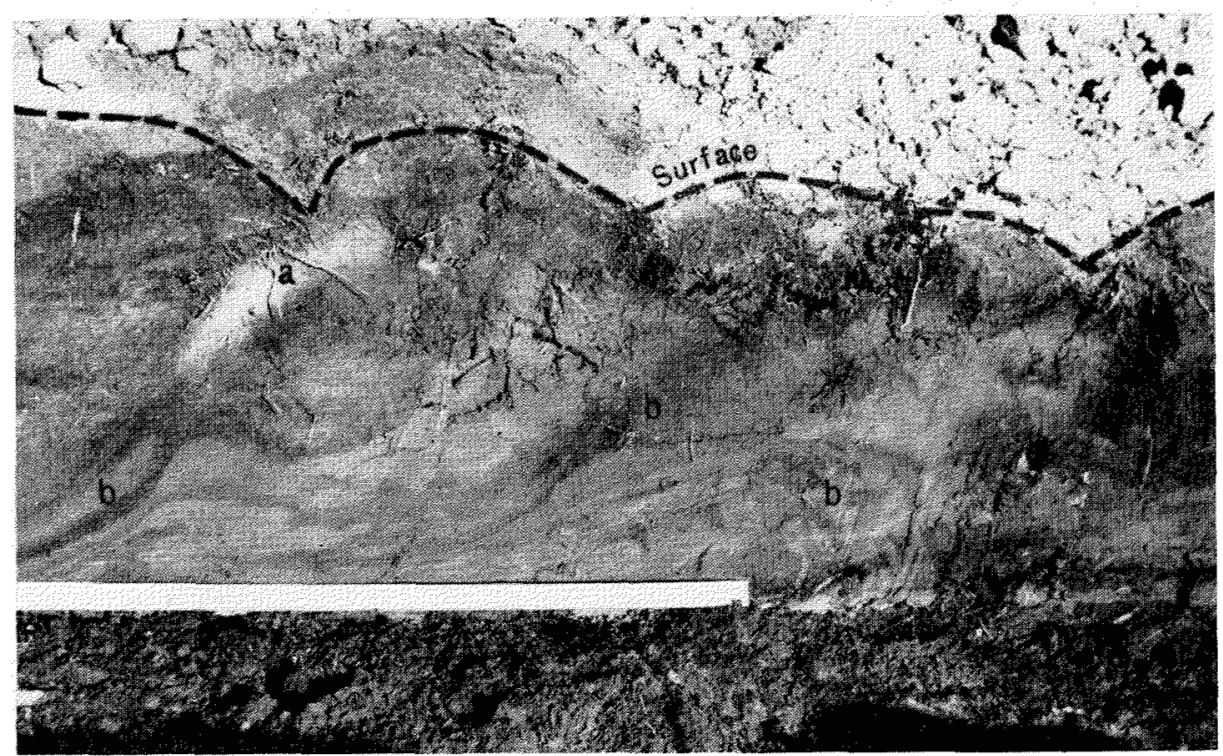

Fig. 7. Overturned and disturbed beds on the southwest side of the plateau. The surface slopes about $4^{\circ}$ to the right. a) greyish-white calcareous silt (specimen 9), which typically occurs under inter-hummock depressions; b) brownish sands with dark brown to black humic lenses, in places overturned in the down-slope direction. Under the yardstick, of which 3 inches lie outside the photograph, is a 1- to 3-inch mucky organic layer over ground ice, which lay (August 19) at a depth of about 26 inches below the surface. The ground ice had veinlets of sand 0.25 to 0.50 inches thick, dipping steeply to the west.

A layer of olive-grey clay fully 2 feet thick has been exposed under olive-grey sand in a pit west of the solifluction lobe, but was not reached in the excavations of the Buffalo Pit itself, although small pods of sandy clay were encountered at a depth of 34 to 36 inches. This clay was found to contain marine microfossils (Table 2, specimen 11). Since 2 of these species are also found in the yellow-green clay and 3 in the olive-grey clay of the crest and higher slopes, and only 2 are confined to this sample, a 
correlation with either clay layer, if they are distinct, is reasonable. The distribution and extent of the clay at this spot is, however, problematical.

\section{Southeast slope of the plateau}

Vegetation and microtopography. Most of the southeast slope is characterized by shrubby willows 2 to 6 feet apart, prostrate willows (Salix reticulata), bearberry, blueberry, grasses, and sedges 12 to 15 inches high, lupins, mosses, etc. Tundra polygons, up to 100 feet across and characterized by bounding depressions a few feet wide and several inches to 2 feet deep, are well developed (Fig. 8). The depressions, which are frequently occupied by standing water, are notable for their willows, mosses, and sedges. Bare mud boils, elongated down slope, are present. Down-slope stripes are also conspicuous. The average inclination of the slope is $3^{\circ}$ to $5^{\circ}$.

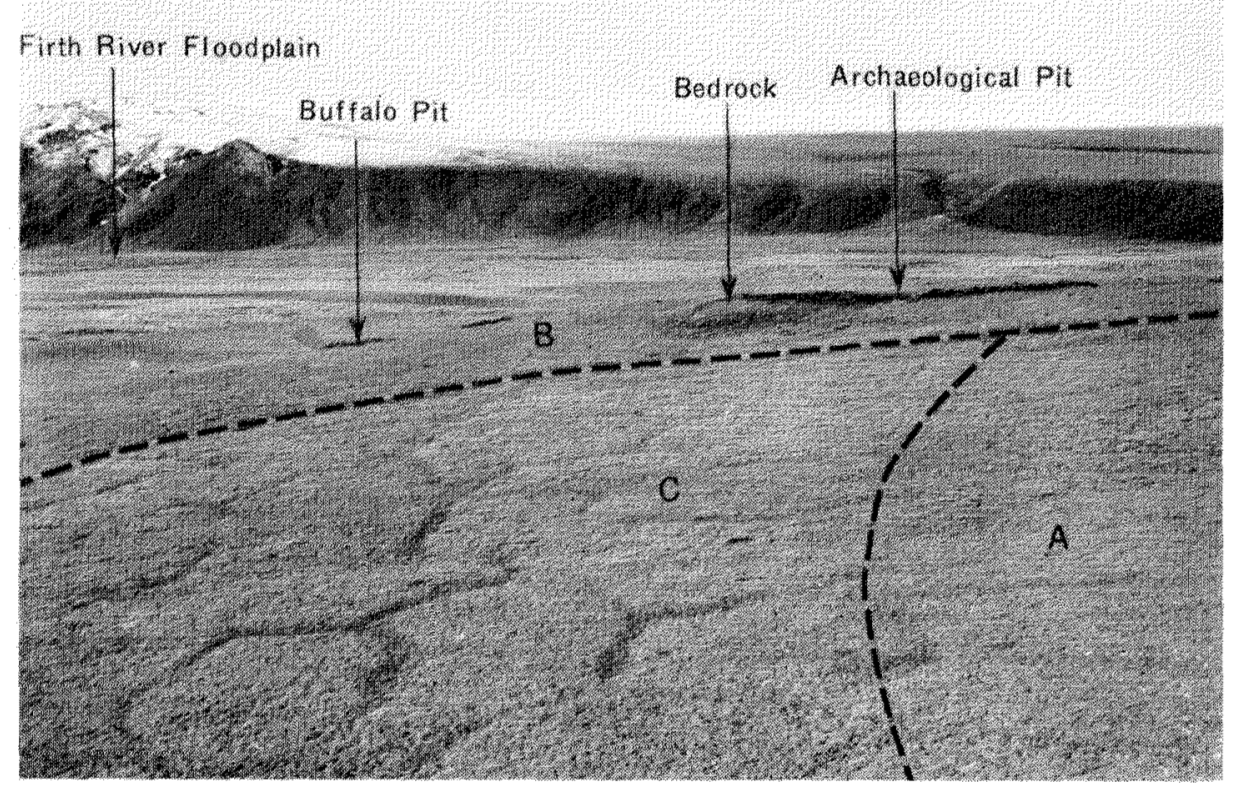

Fig. 8. View taken from the top of Engigstciak looking across the plateau to the hills on the west side of Firth River. Regions A, B, and C refer to those of the text and Fig. 3. Note the well-developed tundra polygons in region $\mathrm{C}$.

The lower slope, below about the 425-foot contour, has fewer willows, but a dominant cover of avens (Dryas), with some prostrate willows (Salix reticulata), bearberry, and mosses. Tundra polygons are smaller and less well developed or absent. In some places tussocks are abundant.

Soils. Olive-grey clay, continuous with that of the crest of the plateau, rests on and has apparently overridden olive-grey and humic sands, like those to the west. This clay extends from 300 to 600 feet down from the crest 
of the slope. Lower down on the slope humic or olive-grey sands or both are present at the surface. Layers rich in organic matter occur at various depths in many pits, but one, at or immediately above the permafrost table, is evidently the equivalent of the organic layer of the crest and north slope of the plateau. The turf horizon varies with the vegetation and nature of the underlying soil.

\section{Relationships among the three areas}

The marked contrast between the clay succession of both the crest and north slope of the plateau and the sand succession of the western and southern slopes was the subject of careful investigation. Numerous pits dug along the contact showed interfingering relationships of many of the layers, and olive-grey and humic sands overridden by olive-grey clay on the southeast slope. The complex folding - and faulting on steep slopes - of clay and sand of the southwest slopes provided at least locally an explanation of the interfingering relationships. Even though the lateral extent of a single pit may have been insufficient to show faulting and folding it is likely that this mechanism is widespread and a major factor in accounting for the observed relationships. Certainly, original interfingering of a quietwater marine clay up-slope with a contemporaneous littoral or aeolian sand down-slope is not possible unless tilting of the land surface is assumed to a far greater extent than is reasonable with any known postglacial tectonic movements or with growth of ground ice. Even the organic layer at or immediately above the permafrost table, which at first seemed to be a reliable stratigraphic horizon suitable for correlating the two distinct successions, proved to be discontinuous, and with two distinct hypotheses regarding its mode of origin (discussed later) its stratigraphic value is seriously in doubt.

\section{E. Ground ice}

Ground ice, with only minor amounts of included foreign matter, is frequently encountered in pits that are dug a few inches below the permafrost surface (Fig. 5), especially in areas of cohesive soils, such as sandy to silty clays. Although ground ice may originate in a variety of ways and occur in different shapes and places, probably most of the nearly pure ground ice in the Engigstciak area has grown in situ either as ice-wedges below the fissures of tundra (ice-wedge) polygons (Fig. 8) or as tabular ice-sheets whose upper surfaces are generally parallel to the base of the active layer and lie slightly below it. As Fig. 8 shows, in some areas, principally on the southeast slope and crest of the plateau, tundra polygons with prominent fissures are numerous. The fissures are spaced from about 50 to 100 feet apart and, judging from fissures of similar size along the nearby coast where ice-wedges have been measured, those of the Engigstciak area are probably more than 2 feet in width where they flare out near the permafrost surface. Many of the wedges probably measure 5 to 10 feet across. At a conservative estimate, therefore, ice-wedges probably occupy 
at least 5 per cent of the upper part of the permafrost zone. In addition, tabular ice-sheets may be present. Such ice-sheets are frequently exposed along the arctic coast, where individual sheets range from a few inches to tens of feet in thickness. One example of the occurrence of ground ice may be given for one of the larger archaeological excavations near the crest of the plateau. Below the turf there was about 10 inches of granular olive-grey clay, then 4 inches of humic sand over a 4 -inch organic layer, then 2 inches of olive-grey sand and then frozen sand at a depth of 21 inches below the surface, the date of excavation being August 23, when thawing would be near its maximum extent. An area measuring 10 feet square was cleared to ground ice and a pit dug 24 inches into the ice without penetrating it. Inasmuch as ground ice is frequently encountered in pits dug in areas without fissures, and ground ice occurs below fissures, the cumulative effect of the growth of ground ice on the microrelief must be appreciable and therefore leads to considerable disturbance of the covering strata.

\section{The stratigraphic hypothesis}

In the early stages of the field work the two sequences of layers described above were regarded as stratigraphic successions complicated by a rapid facies change and later disturbed by frost heaving and solifluction. On the basis of this assumption, the following Quaternary history could be inferred.

(1) Marine submergence to at least the present 530-foot level (and fully 60 feet above the highest point on the plateau, as shown by foraminifera present in the glacio-marine clays) accompanied by deposition of the yellow-green glacio-marine clays. This submergence presumably coincided with an advance of Pleistocene ice into Mackenzie Bay and westward to the vicinity of the site. Such ice would supply the granite and gneissic stones in the clays. Isostatic sinking of the land would have accompanied the ice advance, hence the submergence. The climate would have been either cold or moist to promote the ice advance. Human occupation of the site would have been precluded by the submergence.

(2) Emergence, coinciding presumably with retreat of the ice sheet and accompanying isostatic uplift. Land, at least down to the 415-foot level, would have been exposed and available for establishment of a land vegetation, now recorded in the organic layer, and for human occupation. The climate, judging from pollen incorporated in the organic layer, was warmer than at present. However, as there is an apparent lack of any soil profile development in the clays below the organic layer, the period of emergence was probably brief. Some littoral and aeolian sands may have accumulated at this stage on the southwest slope of the plateau.

(3) A second submergence to an altitude of at least 680 feet (i.e. fully 110 feet above the highest point of the plateau) leading to the deposition 
of additional littoral sands on the southwest slope and then at its climax to that of the olive-grey clays, notably on the crest and north slope. This submergence can again be attributed to isostatic sinking of the land with a second ice advance brought on by a cooling or moistening of the climate. Erratic stones would then be contributed to the area by glacial ice or icebergs. To account for the abnormal thinning of the clays down the southwestern slope, it might be suggested that this part of the site lay within the Firth River estuary where there was clearer water than on the opposite side of the plateau facing the ice-front. Less sediment might be expected to settle from this clearer water, during the period of submergence, than in the area farther to the northeast.

(4) A second and final emergence continuing until modern conditions were attained. During this stage littoral, fluviatile, and later aeolian sands would have accumulated, notably on the southwest slope, contributing to the humic sands and the turf. During this stage conditions would again have become suitable for human occupation.

According to the history thus postulated the oldest of the cultural remains, in the organic layer immediately above or partly in permafrost, would be of interglacial or interstadial age. Because of very large gaps in the records of glacial history between the mid-western states and the Yukon coast (cf. Péwé et al. 1953, Detterman et al. 1958, Hopkins 1959), it is not possible in our opinion to correlate the local records of ice advance with those of the classic area, but possibly the two advances of our stages (1) and (3) may correspond to two stages of the Wisconsin glaciation.

When in later field work a considerable volume of evidence was gathered that was not in accord with the preceding stratigraphic hypothesis, doubts were raised as to its validity. The principal objections are as follows:

1. Lack of an erosional surface below the organic layer: with the retreat of marine waters early in stage (2) of the history, waves could be expected to lap against all parts of the area, particularly on the seaward or north slope of the plateau, from the crest (altitude 475 feet) down to or below the 415-foot level. Although the tough stony clay is admittedly resistant to wave action, at least some removal of fine fractions and redistribution of coarser products as a veneer of sand or pebbles is to be expected. Yet only a few pits out of more than $50 \mathrm{dug}$ on the crest and north slope showed any sand or gravel between the organic layer and the underlying clay, and other evidence suggests this sand and gravel may be a pre-glacial lacustrine shoreline deposit. Evidence of wave action during the first emergence is thus generally lacking.

2. Lack of weathering in the clay below the organic layer: although it has been suggested already that the period of emergence in stage 2 was brief, nevertheless a withdrawal of the sea in excess of 55 feet vertically from the crest of the plateau, followed by the accumulation of many inches of peaty materials - which have been compressed to form an organic 
layer several inches thick - and this in turn followed by a rise in sea-level again in excess of 55 feet, should have involved sufficient time to produce some profile development in the near-surface clay. Particularly disturbing was the complete lack below the organic layer of textural, structural, and colour changes like those of modern tundra soils (Tedrow et al. 1958. Tedrow and Cantlon 1958).

3. Lack of erosional surface above the organic layer: with the second advance of the sea, early in stage (3), wave action would be expected to have attacked the organic layer rather than blanketing the surface, to have truncated it at least locally, and in other places to have buried it in littoral sands. To illustrate with a modern example, the present arctic coast, 15 miles north of the site, is of similar unconsolidated sands and clays, and yet it is being cut back at an estimated rate of from a few inches to a foot or more each year (cf. MacCarthy 1953). Once again no such signs of erosion were detected, nor even on the north slope any traces of beach sands; instead, the organic layer seemed to grade upward into the overlying clays and indeed to be locally continuous with the present turf of the hummock cracks (Fig. 5).

4. The freshness of some plant remains in the organic layer: with the extended history following stage (2) there should have been ample opportunity for decomposition of plant remains in the organic layer laid down at this time. The freshness of occasional greenish willow leaves and shreds of yellow-green sphagnum moss in otherwise decomposed material seemed incompatible with great age. Care was taken to determine whether such fresh plant fragments could have been introduced by burrowing animals, but the unbroken nature of the higher organic and clay layers at the site of deposition seemed to preclude such an explanation.

A corresponding problem was raised by the $\mathrm{C}-14$ dates 1560 and 3208 years B.P. determined from plant fragments and the antler in the organic layer. Such dates are wholly out of keeping with correlations with any interstadial interval in the Wisconsin (cf. Hopkins 1959), let alone a preWisconsin interglacial stage. Indeed it is questionable whether a submergence exceeding 55 feet, followed by deposition of roughly 2 feet of glacio-marine stony clays and this again followed by a 475 -foot emergence and the simultaneous disappearance of a major ice sheet, could all be accomplished during the past 1560 years. Doubt might be cast on the $\mathrm{C}-14$ dating because of contamination of the sample by young material; indeed, fresh white and elastic rootlets, probably of grass or sedge, have been found penetrating at least 12 inches into permafrost below the organic layer. These may be of living plants (cf. Dadykin 1950) although their continuity with plants on the surface could not be established. However, the amount of such modern organic contaminants necessary to produce apparent ages of 1560 and 3208 (or 4000) years from Wisconsin remains is in excess of 50 per cent (Broecker and Kulp 1956) and would be readily detectable. 
The material from which the 1560 date was obtained consists of partly decomposed and discoloured willow twigs or root fragments, not in situ, and care was taken to avoid contamination by any younger material. Rechecking of the C-14 age in the Michigan isotope laboratory, moreover, did not significantly change the date. The antler from which the second date was obtained is likewise free from visible contamination.

5. Similar development of the organic layer on different substrata: at two separate localities in the archaelogical excavations the organic layer was found to transgress from a substratum of clay or sand to bedrock with no significant change in thickness or character. Were this a humus layer accumulated in situ its development on bedrock should be scanty to lacking as compared with that on a sand or clay subsoil.

6. The occurrence of organic layers below an altitude of 380 feet: organic layers occur in pits dug on an upper Firth River terrace at an altitude of 360 to 380 feet. As the terrace shows channel marks and is associated with a higher stage of the Firth River in postglacial times, the organic layer cannot be a buried soil profile of an interglacial or interstadial stage.

7. The abruptness of the change in stratigraphy from the north to the southwest slope of the plateau: although an explanation has already been offered to account for the change from a predominantly glacio-marine clay on the north slope to a predominantly sandy succession on the southwest slope, the change from one to the other should be gradual. It was found, however, that the change in several places took place within a belt less than $\mathbf{5 0}$ feet wide, and that this belt, moreover, showed almost no relationship to the existing topography.

The difficulties outlined are collectively so overwhelming that the authors have become convinced that the stratigraphic hypothesis is untenable.

\section{Alternative explanation of the organic layer}

An organic layer lying close to the permafrost surface below a cohesive soil, such as clay, is not a peculiarity of the Engigstciak archaeological site, but, as shown by field observations and a survey of the literature, is widespread along the western arctic coast from Cape Bathurst $\left(128^{\circ} \mathrm{W}\right.$.) to Point Barrow $\left(157^{\circ} \mathrm{W}\right.$.). (Mackay 1958$)$.

G. Lowther (personal communication) has found a similar buried organic layer with artifacts on permafrost in the Porcupine River area $\left(68^{\circ} 22^{\prime} \mathrm{N}\right.$. $140^{\circ} 27^{\prime} \mathrm{W}$.; $67^{\circ} 35^{\prime} \mathrm{N}$. $138^{\circ} 20^{\prime} \mathrm{W}$.; and $67^{\circ} 37^{\prime} \mathrm{N}$. $139^{\circ} 43^{\prime} \mathrm{W}$.) south of the British Mountains, far removed from any marine submergence, and Mackay has noted buried organic layers at an altitude of about 4,000 feet 
in the unglaciated area of the headwaters of Blow River $\left(66^{\circ} \mathrm{N} .138^{\circ} \mathrm{W}\right.$.) Tedrow et al. $(1958$, p. 36$)$ state that "the upper portion of the permanently frozen layer ... containing considerable organic staining and pieces of organic matter" is so typical of tundra soils of the Arctic Slope of Alaska that this "organic layer" should be considered a master horizon of an idealized tundra profile. In addition, the thickness of silt or clay covering the organic layer, both at Engigstciak and in the many coastal exposures extending over a horizontal distance exceeding 100 miles and a vertical range of many hundreds of feet, is so uniform, (about 2 feet) that it is difficult to attribute such uniformity in thickness to deposition under such varied conditions during a period of submergence. It would appear, instead, that the depth of this organic layer is controlled by the thickness of the active zone and thus is a product of an essentially modern environment in which the position of the permafrost table is established under terrestrial conditions in an arctic climate. At Engigstciak, and in the Firth River area, moreover, some of the organic layer can be demonstrated to consist of surface detritus, twigs, and leaves, rather than of the decomposed remains of a concentration of roots which might have spread out over the "thermal hardpan" immediately above permafrost.

Burial of a surface organic layer by solifluction can be considered especially on the lower slopes where topographic evidence of this process is so clear (cf. Sigafoos and Hopkins 1952). Below the leading edge of a solifluction lobe the sod of the lobe itself tends to be rolled under, like a tractor track, and laid in an inverted position on the surface of the overridden substratum. An extra thick mat of organic matter could be formed in this way. The thickness of the leading edge of an active soliflution lobe is likely to be no greater than the thickness of the active layer, and the original vegetation mat initially would be buried at approximately the depth of the permafrost table. Therefore, after the original vegetation mat was buried, the permafrost table would probably rise to approximately the position of the buried mat. To this extent a solifluction hypothesis can explain some features of the organic layer. However, with continued movement of the trailing part of the solifluction lobe the organic layer could become more deeply buried, especially on an upwardly concave slope, or become partially uncovered especially near the crest of an upwardly convex slope. The organic layer formed in this way would also grade both downward and upward into mineral soil. However, the solifluction hypothesis cannot explain burial on the crest of a ridge where the organic layer of the Engigstciak site seems best developed. Thus, whereas a solifluction hypothesis has local application, it is inadequate to account for all occurrences at Engigstciak.

Continuity of the buried organic layer with the surface sod through curtains of soil rich in organic matter below the cracks separating hummocks (Fig. 5), and the coincidence of the upright or inclined axial planes of anticlinal folds in the buried humic sands with the cracks has already been mentioned. These suggest soil movements under individual hummocks 
extending downward to permafrost. It may be suggested therefore that the surface vegetation mat has been gradually rolled outward and downward below the surface by frost movement, and has been deposited on top of the permafrost during the slow down-slope creep of the hummocks themselves (Mackay 1958). This hypothesis of 'progressive burial' or of 'rolling-under of the surface and of smearing it on the permafrost' bears a relationship with the mechanism occurring at the leading edge of a solifluction lobe, but is restricted to a multitude of small areal units, like honeycomb cells, only a few feet across that function at the crest of a slope as well as at its foot. As with solifluction, the organic layer becomes buried by a mass of soil with a thickness approximately equal to that of the annual depth of thaw. There seems to be no general tendency for the organic layer, once buried, to return to the surface by a convective movement, such as has been postulated by Hopkins and Sigafoos (1951, pp. 81-3) for some frost scars; instead the depth to the organic layer may be reduced only by gradual loss of soil from the surface, or increased by injection of new material from below the organic layer as a result of down-slope movements (cf. Wiggins 1951, p. 42). In all probability the organic material, once rolled under into the deeper part of the active layer remains essentially inert, being in a thawed state and capable of flowing only during a short period of each year, or perhaps only once every few years. In support of this argument is the fact that contortions in the humic sands die out downward from middepth of the active zone.

The precise mechanism influencing movement within the cells remains uncertain, as does the process whereby the cells first become established. However, a series of events in the evolution on, for example, the marine clay can be postulated. In the initial stages, as a vegetation mat was developing, possibly a non-sorted net (Washburn 1956) came into existence by contraction during chilling of already frozen ground or, possibly, during desiccation. Such nets are common at the present time on the bottoms of freshly drained lakes. Alternatively, frost scars, surrounded by peat rings (Hopkins and Sigafoos 1951, p. 81) may have developed. In any event, the cells and associated surface hummocks, once established, seem to have retained their identities over long periods of time. With accumulation of a relatively deep layer of organic matter in the cracks, and with only a scanty layer over the hummock centres, differential freezing and thawing would result. The raw mineral soil of the hummock centres would freeze downward more rapidly than the adjacent material rich in organic matter (cf. Benninghoff 1952) below the cracks, and the development of ice lenses would cause it to swell. With the return of summer conditions the mineral soil of the hummocks would thaw downward more rapidly than the organic material of the cracks, it would tend to spread outward by gravity and carry with it any vegetable material. Such movement within the cells would be particularly accentuated in a down-slope direction, and on a sufficiently steep slope might even lead to overriding of one cell over its next lower neighbour. 
The slowness of the rolling-under movement is shown by the disposition of the archaelogical remains. Artifacts, possibly ancestral to the Eskimo of the Yukon arctic coast, occur in the surface cracks. Dwarf willows, shrub birch, and rhododendron growing on the hummocks or the sides of the depressions may be tens of years if not a hundred years old. A C-14 date indicates, however, that at least some material can be completely buried within an interval of 1560 years. Tedrow and Douglas (1958) have reported C-14 dates of organic layers (which they do not consider to be buried profiles) in the Point Barrow area as ranging from 5,300 to 10,000 years B.P.

Down-slope creep of cells must also be slow. A down-slope movement of only 10 feet in a few thousand years would result in several hummocks overriding any given point on the permafrost table, far more than sufficient to deposit a continuous layer of organic matter. If the down-slope creep was much more rapid one would expect the loss of mineral soil from the crest of the slope to have led to significant shallowing of the depth of the organic layer, and the accumulation at the foot of the slope to a deeper burial. Instead the depth shows but little relationship to gross topography, although it is true that on the crest of the plateau the organic layer may lie a few inches above permafrost and on the lower slope it may be absent or inacessible. However, in view of both the known discontinuities in the organic layer and the possibilities of a shift in the position of the permafrost table with climatic change, this argument may have little significance.

Notwithstanding the uncertainties regarding details of the mechanisms and rates of the movements suggested here, the progressive burial hypothesis seems to offer an explanation of the buried organic layer far more in keeping with the field observations than does the stratigraphic hypothesis originally considered.

\section{Altitude of the marine clays}

A puzzling feature of the marine clays is their occurrence at Engigstciak at an altitude far higher than any known marine limits either to the west or the east. For the fossiliferous marine clays to be deposited, sealevel must have stood somewhere above the present 530 -foot and below the 680-foot contour. Yet there are no high level marine features observable along the Yukon coast west of Firth River. From Demarcation Point (40 miles west of Engigstciak) to Point Barrow, there is no evidence of marine submergence other than the Flaxman formation, with its ice-rafted glacial boulders (Leffingwell 1919, MacCarthy 1958) at altitudes of less than 25 feet above sea-level. To the east of the site, there is also no evidence of a major submergence. Five samples of clay from sites between Firth River Herschel Island in the west and Shingle Point in the east at altitudes of 180 to 680 feet have yielded no marine fossils. Within a few miles of the archaeological site itself, glacial meltwater channels, leading from a succession of ice-dammed lakes, which formed between ice to the north and 
the British Mountains to the south, lie below the present 300-foot contour. Similar meltwater channels occur below an altitude of 300 feet as far east as Blow River. Thus sea-level was below the 300 -foot contour when the latest ice-sheet was at, or close to, its maximum extent.

Marine clays have nowhere been found to mantle these channels nor any of the fluvio-glacial deposits and raised deltas near Engigstciak. Clays are generally absent on these fluvio-glacial deposits and deltas and such clays as have been found in two small isolated patches have yielded no marine fossils (Table 2, specimens 14 and 15).

The problem of accounting for the lower marine clay is common to both the stratigraphic and the creep hypothesis. The lower marine clay might have been deposited long before the last ice-advance and so the record of submergence might be obscured. However, according to the stratigraphic hypothesis, two marine invasions are required, and it is therefore doubly difficult to explain away the lack of record of the second submergence in adjacent areas. However, an alternative ice-thrust explanation for the origin of the anomalous altitude of the marine clay may be suggested.

The capability of glacier-ice to deform sediments on an extensive scale is well known, with numerous examples being cited by Charlesworth (1957, pp. 255-62) and Flint (1957, pp. 88-91). Evidence of thrusting by glacier-ice has been found at several points along the arctic coast within the area affected by the ice lobe that occupied Mackenzie Bay (Mackay 1956). Pleistocene beds folded, faulted, and thrust into topographically high positions have been found at Nicholson Peninsula $\left(129^{\circ} 00^{\prime}\right.$ W.) (Mackay 1957), Shingle Point $\left(137^{\circ} 27^{\prime}\right.$ W. $)$, King Point $\left(138^{\circ} 00^{\prime}\right.$ W. $)$, Kay Point $\left(138^{\circ} 22^{\prime} \mathrm{W}\right.$.) and at Herschel Island $\left(139^{\circ} 00^{\prime}\right.$ W.) (Mackay 1959).

To the south, in Alberta and Saskatchewan, somewhat similar icethrust features have also been observed (Gravenor and Bayrock 1955, Byers 1959, Hopkins 1923, Horberg 1952, and Slater 1927). The problem of glacier-ice thrust will be discussed more fully in a later paper, but for the present, it is suggested that glacier-ice thrust may have shoved the marine clays to their present anomalously high position.

\section{Summary}

Notwithstanding the common succession of layers at the archaelogical site - marine clay overlain by terrestrial organic matter with artifacts, and this by more marine clay, which extends to the surface sod - this cannot be accepted as a stratigraphic sequence representing two marine invasions, with intervening and succeeding periods of emergence. The evidence suggests rather only a single marine invasion, coincident with an advance of glacier-ice. The marine invasion, moreover, may not have reached the present altitude of the archaeological site, but instead the marine beds laid down during this invasion may have been thrust up by glacier-ice into their present position on the northeast slope and the crest of the Engigstciak 
plateau. Here, as a result of movements within the surface soil brought about by freezing and thawing and by down-slope creep, organic matter and artifacts have been subsequently incorporated into the clay as a more or less distinct layer at the base of the active layer. Some marine clay has in all probability moved down the southwest slope of the plateau, where it has come to rest on a sand deposit, which originated independently. The marine clay together with surface vegetation and archaeological remains has lately been incorporated into the sand.

From these conclusions about the geological origin of the soils, it follows that all artifacts and associated organic detritus in the clay areas of the site postdate the last glaciation of this area, whatever this may correspond to in the classical Pleistocene successions of more temperate latitudes. Artifacts found in the sands of the southwestern part of the site are probably also postglacial, although there the relationship is less clear. In any event, it is also concluded that in the clay areas of the crest of the plateau the depth at which the artifacts are now found has very little significance, except that there was time and opportunity for older remains to become more deeply buried than younger ones. In the sandy areas of the south slope the evidence of disturbance is clear in the upper horizons, and a buried muck layer occurs on the higher slopes. There also inversion may have taken place and the depth of the artifacts may have little age significance. In the Buffalo Pit, however, both the gradational contact between the humic sands and the underlying streaky sands, and the sharp contact between the streaky sands and the underlying yellowish sand are relatively free from disturbance, with no signs of involutions. It appears, therefore, that the artifacts, bones, and pollen from the humic sands have not been derived from the underlying streaky and yellowish sands, and vice versa. It seems reasonable that there the artifacts, etc., from the humic sands are younger. Elsewhere at this site the archaeological complexes will have to be dated and correlated on archaeological considerations or by C-14 analyses of animal remains, mainly bones and teeth, or of charcoal, rather than of coincidentally associated plant matter.

Although the geological investigations have provided no significant help in dating the archaeological remains, the archaeological material has, on the other hand, proved invaluable in the study of the more complex soil movements, hitherto very poorly understood, which take place in this arctic environment.

\section{Acknowledgements}

The writers should like to express their thanks to all those who have rendered assistance in the investigation of the Engigstciak archaeological site. The Topographical Survey, Department of Mines and Technical Surveys, Ottawa, has prepared a map of the Firth Valley on a scale of 1:31,680 with a 20 -foot contour interval. This map was drawn from air photographs using altitude control established by readings taken with a set of precision 
altimeters at selected helicopter landing points. Determinations and identifications were carried out by Dr. F. Wagner (Geological Survey of Canada) on marine microfossils, Dr. J. Terasmae (Geological Survey of Canada) on palynology and wood fragments, Mr. J. A. Pihlainen (National Research Council of Canada) on the Firth River soils, Dr. A. W. F. Banfield (National Museum of Canada) on caribou bones, Mr. W. Langston (National Museum of Canada) and Dr. A. W. Cameron (Redpath Museum, Montreal) on horse and other bones, and Dr. A. Skinner (American Museum of Natural History) on buffalo and other bovidae. The C-14 analyses were done for Dr. R. S. MacNeish at the University of Michigan and the University of Pennsylvania. Dr. J. G. Fyles and Mr. G. Lowther have contributed helpful suggestions on the manuscript and Dr. D. M. Hopkins has been of considerable assistance to the authors by critically reviewing the paper. Support for the study of Mackay and Mathews in 1956 was from a grant of the Banting Research Foundation provided by the Arctic Institute of North America, and that for Mackay in 1957 from the Geographical Branch, Department of Mines and Technical Surveys, Ottawa.

\section{Appendix 1 - Soil mechanics}

Supporting evidence for the origins of and differences between fluvioglacial and marine clays, which is especially important in the absence of microfossils and convincing geomorphic evidence, may be obtained from an analysis of their plasticity (liquid and plastic limits in the Atterberg system) and grain size as shown in Figs. 9 and 10. In Fig. 9, the plasticity index (i.e. difference between liquid and plastic limits) is plotted against percentage of clay. As Skempton (1953) has shown, "inactive" clays that plot below the 0.75 activity value seem to possess one or more of the following characteristics: a composition with little clay mineral, deposition in fresh water, and deposition in salt water with subsequent leaching by fresh water. The low activity value (mainly less than 0.5 ) of Firth River clays is in keeping with that of glacial clays and leached marine clays.

Differences between the fluvio-glacial clays and marine clays show up clearly on Casagrande's (1948) plasticity chart for soil classification in which the plasticity index is plotted against the liquid limits, Fig. 10. Specimens 1, 4, 8, 10, and 11 are olive-grey and yellow-green clays from the Engigstciak site. They are inorganic clays and lie above the A-Line. Specimens 6 and 7 are yellowish-green clays, which lie under organic layers. Although their grain-size differs little from that of the preceding specimens, apparently a slight addition of organic colloidal matter has increased the liquid limit so that the two specimens fall in the zone typical of organic and inorganic silts and clays. Glacial rock flour typically lies below the A-line, as with specimens 15 and 16. Specimen 15 is from soil on an esker and 16 from what is believed to be non-marine clay. Specimen 14 is from the surface of a delta and so might be of rock flour, like specimens 15 and 16. 


\section{Appendix 2-Bedrock geology}

In the area a quarter of a mile square west of Engigstciak the most conspicuous rock type is smoky grey chert, occurring in beds mainly 2 to 4 inches thick and commonly separated by shaly partings. There are about 100 feet, stratigraphic thickness, of irregularly folded beds exposed in the

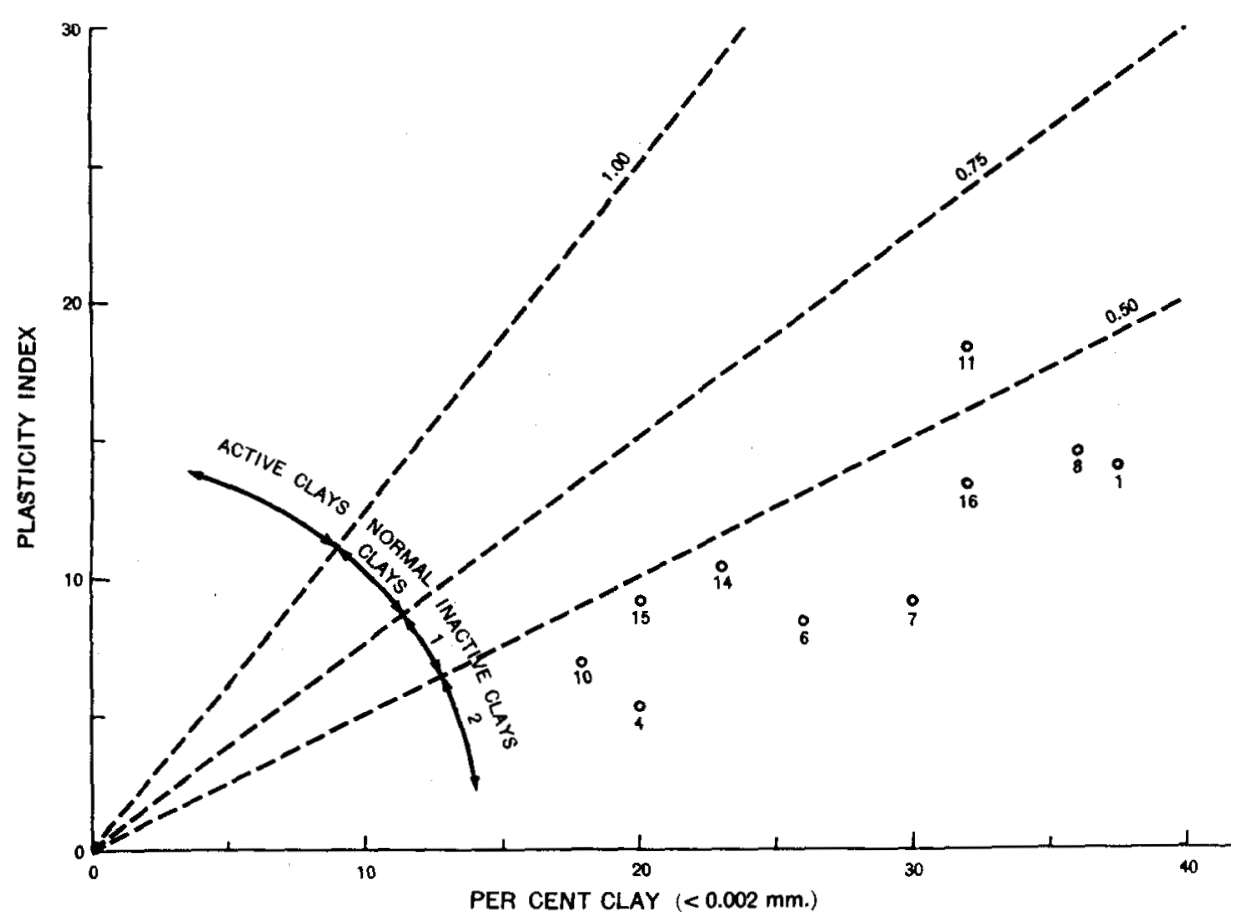

Fig. 9. Activity graph, after Skempton (1953) and Bjerrum (1954). Numbers are those of specimens referred to in Appendix 1.

core of an anticline plunging to the northwest in the southwestern part of the area, and a similar thickness in a second anticline, also plunging to the northwest, making up the rocky hill Engigstciak. The chert is flanked on the southwest along Firth River by several hundred feet of unfossiliferous black, brittle shale with minor interbedded ironstone. Although the contact with the chert is not exposed, this shale probably rests conformably on the chert. The chert is flanked on the northeast by approximately 100 feet of tightly folded pale shale, in part siliceous, that weathers to a cream colour. Although this may be an altered equivalent of the black shales, it seems more likely to be a different stratigraphic unit in fault contact with the chert. Interspersed with outcrops of the pale shale along the east bank of Firth River are two different exposures of light grey, thick-bedded, gently dipping, coarse-grained to pebbly, bioclastic limestone containing 
crinoid columns, indeterminate gastropods, and sand-sized detritus of what are believed to be trepostomatous bryozoans. If the latter identification is correct and bryozoans are contemporary with the sediment, the limestone is Paleozoic. The limestone-shale contact is not exposed, but the marked discrepancy in dips suggests that the limestone rests unconformably on the highly folded shales.

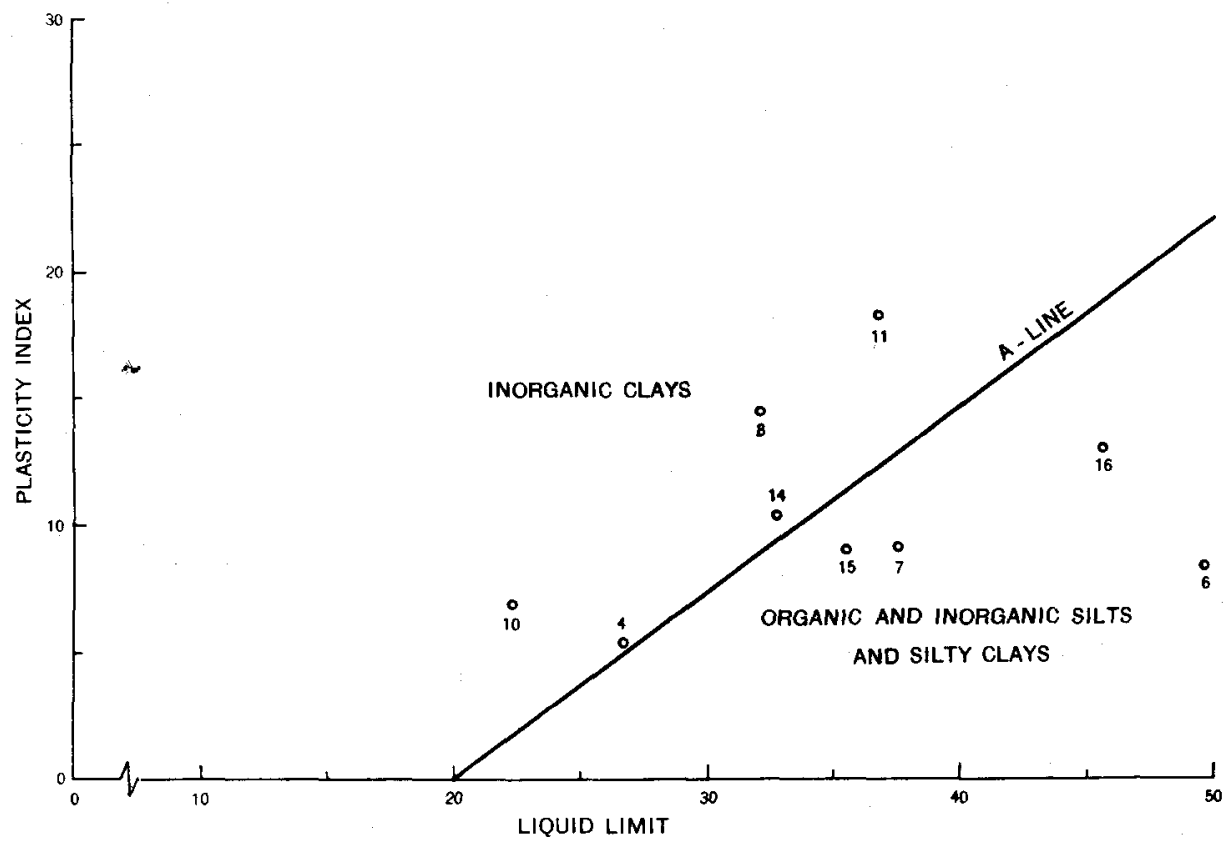

Fig. 10. Relation between the liquid limit and plasticity index after Casagrande (1948). Numbers are those of specimens referred to in Appendix 1.

\section{References}

Benninghoff, W. S. 1952. Interaction of vegetation and soil frost phenomena. Arctic 5:34-44.

Bjerrum, L. 1954. Geotechnical properties of Norwegian marine clays. Géotechnique 4: 49-69.

Bastock, H. S. 1948. Physiography of the Canadian Cordillera, with special reference to the area north of the fifty-fifth parallel. Ottawa: Geol. Surv. Mem. 247, 106 pages.

Broecker, W. S., and J. L. Kulp. 1956. The radiocarbon method of age determination. Am. Antiquity 22:1-10.

Byers, A. R. 1959. Structure of the Whitemud formation near Claybank, Saskatchewan. Roy. Soc. Can., Order of Proc., June Meetings, Abstract, p. 21-2.

Casagrande, A. 1948. Classification and identification of soils. Trans. Am. Soc. Civil Engrs. 113: 901-30.

Charlesworth, J. K. 1957. The Quaternary era. London: Edward Arnold, Vol. 1, p. 255-9.

Dadykin, V. P. 1950. O biologicheskikh osobennostyakh rasteniy kholodnykh pochv. Priroda 39:21-9 (reviewed in Snow, Ice, Permafrost Research Establishment. Bibliography of snow, ice, and permafrost, Abst. SIP U6206). 
Detterman, R. L., A. L. Bowsher, and J. T. Dutro, Jr. 1958. Glaciation on the Arctic Slope of the Brooks Range, northern Alaska. Arctic 11:43-61.

Flint, R. F. 1957. Glacial and Pleistocene geology. New York: John Wiley, p. 88-91. Gravenor, C. P., and L. A. Bayrock. 1955. Glacial geology of the Coronation District, Alberta. Res. Coun. Alberta, Prelim. Rept. 55-1, 38 pages.

Hopkins, D. M. 1959. Cenozoic history of the Bering land bridge. Science 129:1519-28.

Hopkins, D. M., and R. S. Sigafoos. 1951. Frost action and vegetation patterns on Seward Peninsula, Alaska. Washington: Geol. Surv. Bull. 974-C, 101 pages.

Hopkins, O. B. 1923 . Some structural features of the Plains Area of Alberta caused by Pleistocene glaciation. Bull. Geol. Soc. Am. 34:419-30.

Horberg, L. 1952. Pleistocene drift sheets in the Lethbridge region, Alberta, Canada. J. Geol. 60:303-30.

Leffingwell, E. de K. 1919. The Canning River region, northern Alaska. Washington: Geol. Surv. Prof. Pap. 109, 251 pages.

Livingstone, D. A. 1955. Some pollen profiles from arctic Alaska. Ecol. 36:587-600. 1957. Pollen analysis of a valley fill near Umiat, Alaska. Am. J. Sci. 255:254-60.

MacCarthy, G. R. 1953. Recent changes in the shoreline near Point Barrow, Alaska. Arctic 6:44-51.

1958. Glacial boulders on the arctic coast of Alaska. Arctic 11:70-85.

Mackay, J. R. 1956. Deformation by glacier-ice at Nicholson Peninsula, N.W.T., Canada. Arctic 9:218-28.

1957. Structural features formed by glacier ice at Nicholson Peninsula and Herschel Island, N.W.T., Canada. Abstract. Ann. Assoc. Am. Geog. 47:168-9.

1958. A subsurface organic layer associated with permafrost in the western Arctic. Ottawa: Geog. Br. Geog. Pap. No. 18, 21 pages.

p. 5-21.

Mackay, J. R., and W. H. Mathews. 1956. Superficial geology of the Firth River archaeological site, Yukon Territory. Arctic 9:210-11.

MacNeish, R. S. 1955. Archaeological investigations in the Yukon Territory. Arctic 8: 195 .

1956. The Engigstciak site on the Yukon arctic coast. Univ. Alaska Anthrop. Pap. 4: 91-111.

Péwé, T. L. et al. 1953. Multiple glaciation in Alaska: a progress report. Washington: Geol. Surv. Circ. 289,13 pages.

Rainey, F., and E. Ralph. 1959. Radiocarbon dating in the Arctic. Am. Antiquity 24:367.

Sigafoos, R. S., and D. M. Hopkins. 1952. Soil instability on slopes in regions of permanently frozen ground. Washington: Highway Res. Bd.; Frost action in soils: a symposium. p. 176-92.

Skempton, A. W. 1953. The colloidal "activity" of clays. Proc. Third Intl. Cong. Soil Mech. and Foundation Engr. Zürich, Switzerland. 1: 57-61.

Slater, G. 1927. The structure of the Mud Buttes and Tit Hills of Alberta, Canada. Bull. Geol. Soc. Am. 38: 721-30.

Tedrow, J. C. F., J. V. Drew, D. E. Hill, and L. A. Douglas. 1958. Major genetic soils of the Arctic Slope of Alaska. Soil Sci. 9:33-45.

Tedrow, J. C. F., and J. E. Cantlon. 1958. Concepts of soil formation and classification in arctic regions. Arctic 11:166-79.

Tedrow, J. C. F., and L. A. Douglas. 1958. Carbon-14 dating of some arctic soils. Rutgers Univ. Dept. of Soils. Mimeogr. note, 6 pages.

Washburn, A. L. 1956. Classification of patterned ground and a review of suggested origins. Bull. Geol. Soc. Am. 67: 823-66.

Wiggins, I. L. 1951. The distribution of vascular plants on polygonal ground near Point Barrow, Alaska. Contr. Dudley Herb. 4:41-52. 